\title{
Farklı Yaş Grubundan Bireylerin Türkiye'deki Suriyeli Mültecilerin Durumu Hakkındaki Görüşlerinin İncelenmesi
}

\section{The Views of Individuals in Different Age Groups on The Status of Syrian Refugees in Turkey}

\begin{abstract}
Arzu ÖZYÜREK ${ }^{1}$ Pelin Eda KAPÇI ${ }^{2}$ Sedat YILANCI $^{3}$
$\ddot{O} z e t$

Bu araştırmanin genel amacl, farkl yas grubundan bireylerin Türkiye'deki Suriyeli mültecilerin durumu hakkindaki görüşlerini saptamakttr. Araştırma betimsel tarama modelinde tasarlanmuştır. Çalışma grubu Adıyaman ve Ankara illerinden rastgele seçilen 374 kișiden olușturulmuștur. Veri toplamada, yarı yapılandırılmış görüșme formu kullanılmış ve verilerin analizinde içerik analizi kullanılmıştır. Sonuç olarak, katılımcıların Suriyeli mültecilerle aynı dili konuşamadı̆̆g için iletişsim kurmakta zorlandlkları belirlenmiștir. Suriyeli mültecilere maddi ve manevi destek verilmekle beraber yaşanan problemlerin acilen çözülmesi ya da mültecilerin en kisa sürede kendi ülkelerine dönmelerini istedikleri görülmüş̧ür. Suriyeli mültecilerle ilgili olarak işsizlik, istihdam, kültür çatışması ve dil problemleri sorun olarak görülmektedir. Yaşanan problemlerin çözümü için ilk önerilen mültecilerin kendi ülkelerine dönmeleridir. Bu mümkün olmadığında ise Suriyelilere yönelik özelleştirilmiş eğitim programlarının düzenlenmesi ve ülke vatandaşlarına bilinçlendirme çalışmalarının yapılması önerilmiştir.
\end{abstract}

\section{Anahtar Kelimeler Suriyeli mülteciler Göçmenler, Toplumsal kabul, Kültürel uyum,}

\begin{abstract}
The general objective of the present study was to determine the views of individuals in different age groups on the status of Syrian refugees in Turkey. The study was designed as a descriptive analysis. The study group included 374 randomly selected individuals, who resided in the provinces of Adlyaman and Ankara. Study data was collected with a semi-structured interview form. Content analysis was conducted on the collected data. The study findings determined that the participants experienced communication difficulties with Syrian refugees since they could not speak the same language. It was observed that although financial and moral support were provided for the Syrian refugees, the participants stated that either the experienced problems should be urgently resolved, or the refugees should return to their countries as soon as possible. The participants considered unemployment, employment, cultural conflicts and language problems as the problems experienced with Syrian refugees. The first proposed solution for the solution of the experienced problems was sending the refugees to their native countries. If that was not possible, it was proposed to organize specialized training programs for the Syrians and to raise the awareness of Turkish citizens.
\end{abstract}

Key Words

Syrian refugees, Immigrants, Social acceptance, Cultural adaptation,

\footnotetext{
Atıf için:

Özyürek, A., Kapçı, P. E. \& Yılancı, S. (2019). Farklı yaş grubundan bireylerin Türkiye'deki For Citation Suriyeli mültecilerin durumu hakkındaki görüşlerinin incelenmesi. Muğla Sitkı Koçman Üniversitesi Eğitim Fakültesi Dergisi [MSKU Journal of Education], 6(1), 56-69. DOI: 10.21666/muefd.518919

Received: 09.07.2018 Accepted: 25.03.2019 Published: 01.05.2019

${ }^{1}$ Karabük Üniversitesi Sağlık Bilimleri Fakültesi. e-posta: a.ozyurek@karabuk.edu.tr ORCID: 0000-0002-3083-7202

${ }^{2}$ Karabük Üniversitesi Sağlik Bilimleri Fakültesi. e-posta: pelineda3@ gmail.com ORCID: 0000-0001-8303-5652

${ }^{3}$ Karabük Üniversitesi Sağlık Bilimleri Fakültesi. e-posta: sdtylnc@ gmail.com ORCID: 0000-0003-2680-7518
} 
Göç; pek çok sebebi olmakla birlikte bireylerin bulundukları yerde gereksinimlerini karşılayamaması kişisel, ekonomik, siyasal ya da çeşitli çevresel nedenlerle bir yerden başka bir yere yapılan, kısa, orta veya uzun vadede geriye dönme amacı güdebileceği gibi yerleşme amacı da güdülen toplumsal, kültürel ve coğrafi bir yer değiştirme hareketi olarak tanımlanmaktadır (Castles ve Miller, 2008; Beter, 2006; Yalçın, 2004). İnsanlığın var oluşundan bu yana görülen göç, uygarlıkların şekillenmesinde önemli rol oynamıştır. Ekonomik nedenler başta olmak üzere siyasi nedenler ve savaş gibi pek çok neden, insanların göç etmesine neden olmuştur (Giddens ve Sutton, 2014). Dünya genelinde 19802005 yılları arasında yılda 3,6 milyon göçmen nüfus artışı olduğu belirlenmiştir (Li, 2008) ve uluslararası düzeyde göçmen sayısı 232 milyon olarak gerçekleşmiştir. Bunun nedeni ne olursa olsun, göç toplumda sosyal, ekonomik ve siyasi etkiler bırakmaktadır (Kane, 1995).

Hem yetişkinleri hem de çocukları olmak üzere tüm aile üyelerini ciddi şekilde etkileyen göç, yeni yaşam koşullarına uyumsuzluk, dışlanma, yetersiz beslenme ve temizlik, güvensiz ev ortamı, istismar gibi pek çok olumsuz etkileri de beraberinde getirmektedir. Özellikle çocuklar, bundan en fazla etkilenen grup olmaktadırlar (Gözübüyük, Duras, Dağ ve Arıca, 2015; Şener ve Ocakçı, 2014). Göç, özellikle uyum sorunu oluşturmaktadır. Uyum, bireyin hem kendisi hem de çevresiyle iyi ilişkiler kurabilmesi, bu ilişkileri sürdürebilmesi, bulunduğu toplumdaki değer yargılarına uygun hareket etmesi, yaşanan değiş̧imlere uygun davranışlar sergilemesidir (Tatlılığlu, 2012; Kızılçelik ve Erjem, 1994).

Özellikle başka bir ülkeye göç edenlerin yaşamlarını sürdürebilmeleri yeni duruma iyi bir uyum sağlamalarına bağlıdır (Güven, 1996). Dil, din, kültürel benzerlik ve ekonomik durum gibi faktörlerin uyum sürecinde etkili olduğu bilinmektedir. Göçmenler, toplumsal etkileşim sürecinde ya kabul edilmekte ya da dışlanmaktadırlar (Poyraz-Tacoğlu, Arıkan ve Sağır, 2012). Özellikle mesafenin uzun olduğu göçlerde, yaşanan uyum sorunu daha belirgin olmakta, göç edenler özellikle iletişim için gerekli olan dil, kültürel uyumda önemli bir etken olan din, yakın akrabaların olmayışı nedeniyle yabancılaşma, çevreye uyum, ekonomik ve kültürel sorunlar yaşamaktadırlar (Özmen, 2012; Tatlılığlu, 2012; Deniz ve Etlan, 2009; Chambers, 2005; Yalçı, 2004; Küçükkaraca, 2001). Yaşanan uyum sorunlarının çözümünde yerli halkla kurulan ilişkiler önem kazanmaktadır.

Günümüzde göç olgusu, yaşanan çatışmalar ve savaşlar neticesinde çok ciddi bir hal almıştır. Her ülkenin ulusal güvenlik kaygısıyla farklı göç politikaları izlemesi neticesinde, uluslararası anlamda göçmenlerin durumunu sorgulayan ve bu yönde politikalar oluşturmaya çalışan etkin bir uluslararası mekanizma mevcut değildir (Gök, 2016). Suriye'den süregelen göçün ne kadar devam edeceği kestirilememekte ve bu durum çevre ülkelerde pek çok soruna neden olmaktadır (Ağır ve Sezik, 2015; Güçtürk, 2014; Kirişçi, 2014). Bu ülkelerden Türkiye, göç süresinin uzaması ve göç edenlerin sayısının giderek artmasına rağmen Suriyeli mültecileri kabul etmeye devam etmektedir (ORSAM, 2015; ORSAM ve TESEV, 2015).

Türkiye'ye 2011 yılından itibaren, en uzun kara sınırına sahip olduğu Suriye'den göç almaktadır ve uyum önemli bir sorun oluşturmaktadır. Türkiye 2014 yılından itibaren en fazla mülteci barındıran ülke konumundadır. Savaş ortamından kaçarak Türkiye'ye sığınan Suriyeliler için sığınma eylemi nedeniyle "sı̆̆ınmacı" tanımı yapılmaktadır (Duruel, 2017). Uluslararası göçmenlerin bir kısmını silahlı çatışma, doğal afet, zulüm ve kıtlıktan kaçan insanlar oluşturmaktadır. İnsanlar hayatlarını kurtarabilmek amacıyla ve daha iyi yaşam koşulları umuduyla göç etmektedirler (Baş, Molu, Tuna ve Baş, 2017). Suriye'den göçen bireyler için uluslararası hukukta, vatandaşı olduğu ülke dışında olan ve "1rk1, dini, tabiiyeti, belirli bir sosyal gruba mensubiyeti veya siyasi düşüncesi nedeniyle zulme uğrayacağından haklı sebeplerle korktuğu" için vatandaşı olduğu ülkeye dönemeyen veya dönmek istemeyen kişiler olarak tanımlanan mülteci ifadesi (https://bianet.org, 2019) kullanılmaktadır. Bu süreçte Türkiye'deki mülteci sayısı 3,4-3,5 milyona ulaşmıştır. Suriyeli veya diğer milletlerden mülteciler "kent mültecileri" haline dönüşmüşler ve başta İstanbul olmak üzere Türkiye'nin her tarafına yayılmışlardır. Kilis’te mülteci sayısı 130 bini aşmış, Kilis haklı azınlık durumuna düşmüştür. Bunun yanında, zorunlu göç edenlerin çoğunluğunu çocuklar ve kadınlar oluşturmaktadır. Mültecilerin büyük bölümü kamplar dışında halkın içinde yaşamaktadır ve bu durum toplumsal kabul veya bireyler arasında gerginlik yaşanması açısından önem taşımaktadır (Erdoğan, 2017; Yavuz, 2015; Keser ve 
Meral, 2016). Türkiye'de bulunan Suriyelilerin çoğunun gelecekte Türkiye'de kalacakları düşünülmektedir. Bu yoğun göçün ise sağlık, barınma, beslenme, çalışma ve eğitim gibi temel haklar bağlamında çok boyutlu ele alınması gerekmektedir (Kağnıcı, 2017).

Yaşanan iç savaş nedeniyle, göç etmek zorunda kalan Suriyelilerin gittikleri ülkeye pek çok açıdan etkisinin olacağı açıktır. Bu etkiler, geldikleri bölgenin yapısına göre politik, ekonomik ve sosyal etkiler olabilir (Duruel, 2017). Ortadoğu Stratejik Araştırmalar Merkezi (ORSAM) ve Türkiye Ekonomik ve Sosyal Etütler Vakfı (TESEV) tarafından hazırlan "Suriyeli Sığınmacıların Türkiye'ye Etkileri" adlı raporda, sosyal dışlanmanın toplumsal, ekonomik, siyasi ve güvenlik ile temel hizmetler üzerindeki etkileri ele alınmıştır. Türkiye'deki Suriyeliler konusunun sosyal uyum sorunu olarak ele alınması gerektiği vurgulanmış, bunun nedeni olarak dil, kültür ve yaşam tarzından kaynaklanan farklılıkların sorunlara, bu sorunların ise yerel tepkilere neden olması gösterilmiştir. Çok eşlilik ve buna bağlı boşanmalar, kadın ve çocuk istismarı, büyük şehirlerde kira artışı, temel gıda maddeleri ve ev fiyatlarında yükselme, kaçakçılığın boyutunun artması gibi olumsuz etkilerin yanında üretime katılmalarıyla ekonomiye katkı sağladıkları gibi olumlu katkıları da vurgulanmıştır (ORSAM ve TESEV, 2015). Genel olarak düşünüldügünde, temel problemin düzenlenmemiş göçün nasıl yönetileceği konusu olduğu söylenebilir. Uluslararası göçün insani bir hak olduğu bilinciyle hareket edilmediğinde, göç yönetiminde başarılı olunamayacağı açıktır. Suriyeli mültecilerde olduğu gibi, Avrupa Birliği üyesi devletlerin sorunu insan güvenliği açısından ele almayışları göçmenlerin konumunu her geçen gün daha problemli bir hale getirmektedir (Gök, 2016).

Türk toplumu merhamet, hoşgörü, yardımseverlik gibi vicdani duyguları ön planda tutan bir toplumdur. Diğer ülkelerde çıkan savaşlar, doğal afetler vb. durumlarda yaşanan ölümler, toplumun bu duygularının kabarmasına neden olmaktadır. Suriye, Türkiye sınır komşusudur ve pek çok insan iç savaş nedeniyle göç ederek Türkiye'ye gelmişstir. Bu durum Türk toplumunun yaşamını da etkilemiştir. Yerel nüfusun her gün iş, ev veya okul ortamında ortak yaşam sürdürdükleri mültecilerle iletişimlerinde ve kültürel etkileşimlerinde ne gibi değişimler yaşandığını saptamak, ortak yaşantıyı olumlu ve olumsuz yönde etkileyen durumları belirleyerek gerekli tedbirlerin alınması toplumun refahı açısından önemli görünmektedir. Bu nedenle bu çalışmada, Türk halkının Suriyeli mültecilerin durumuyla ilgili görüşlerinin incelenmesi amaçlanmıştır. Bu çerçevede bireylerin mültecilerle iletişimleri ve bu iletişimi etkileyen olumlu ve olumsuz durumlar, komşuluk ilişkileri, mültecilerin şimdiki ve gelecek yaşamdaki sorunlarıyla ilgili görüşleri belirlenmeye çalışılmıştır.

\section{Yöntem}

\section{Araştırma Modeli}

$\mathrm{Bu}$ çalışma nitel araştırma yöntemini esas alan, genel tarama modelinde yapılandırılmıştır. Nitel araştırmalar, doküman inceleme ya da gözlem ve görüşme gibi veri toplama yöntemlerinin kullanıldığ , olayların derinlemesine ve bütüncül bir şekilde ortaya konması süreci izlenen araştırmalar olup elde edilen sonuçlar evrene genellenemez, fakat sonuçlar konuya ilişkin bakış açısı sağlar. Tarama modeli, var olan bir durumu kendi koşulları içerisinde mevcut şekliyle betimlemeyi amaçlamaktadır. $\mathrm{Bu}$ çalışmada sorulan sorulara anında cevap alınması değişen koşullara göre soru niteliği ve sayısının değiştirilebilmesi ve derinlemesine bilgi elde edilebilmesine imkân sunan yarı yapılandırılmış görüşme yönteminden yararlanılmıştır (Ekiz, 2003; Çepni, 2005; Yıldırım ve Şimşek, 2006; Karasar, 2007).

\section{Çalışma Grubu}

Araştırmanın çalışma grubunu, kolay ulaşılabilir örnekleme yöntemiyle kendilerine ulaşılabilen ve çalışmaya katılmaya gönüllü Ankara ve Adıyaman'da ikamet eden 15 yaş ve üzeri 374 kişi oluşturmuştur. Çalışma grubunun \%49,32'si kadın, \%54,84'ü erkek; \%30,21'i 15-20 yaş, \%18,71'i $21-25$ yaş, $\% 8,82$ 'si $26-30$ yaş, \%11,22'si 31-35 yaş, \%9,09'u 36-40 yaş ve $\% 21,92$ 'si 41 yaş ve üzeri yaş grubundadır.

\section{Veri Toplama Araçları}

Çalışmada, araştırmacılar tarafından çalışmanın amaçları ve alan yazın bilgileri doğrultusunda geliştirilen yarı yapılandırılmış görüşme formu kullanılmıştır. Görüşme formu düzenlenirken anlaşılır, 
kısa ve net ifadeler içeren 16 açı uçlu soru oluşturulmuştur. Form, iki alan uzmanının görüşüne sunulduktan sonra iki genç ve iki yetişkin bireyle ön uygulama yapılmıştır. Buna göre gerekli bazı düzeltmeler yapılarak kapsam geçerliği sağlanan görüşme formu 18 soruyla kullanıma hazır hale getirilmiştir.

\section{Verilerin Toplanması ve Analizi}

Araştırma verileri 2017 yılı Temmuz-Eylül ayları arasında, bireysel olarak yapılan görüşmelerle toplanmıştır. Elde edilen veriler, not tutularak kaydedilmiştir. Daha sonra her bir katılımcının görüşleri bilgisayar ortamına aktarılmıştır. İçerik analiziyle analiz edilen veriler kodlanarak sayısallaştırılmış ve bilgisayar ortamında girilmiştir. Veriler beş ana ve dokuz alt kodlama yapılarak ayrılmıştır, bulgular bu kodlar dikkate alınarak temalar halinde sunulmuştur. Bazı bilgiler, yüzde ve frekans dağılımlarıyla verilmiştir. Katılımcıların örnek ifadelerine yer verilerek verilerin geçerliğine katkı sağlanmaya çalışılmıştır. Örnek ifadeler sunulurken katılımcıların cinsiyeti ve yaşını belirten kodlamalar kullanılmıştır. Örneğin; 6.sırada verileri kaydedilen 6K21 21 yaşındaki bir kadın katılımcıyı ifade etmekte, 69.sırada verileri kaydedilen 69E48 ise 48 yaşındaki erkek bir katılımcıyı ifade etmektedir.

\section{Bulgular}

$\mathrm{Bu}$ bölümde, çalışma grubuna ilişkin veriler beş farklı tema altında incelenmiş, yüzde ve frekans dağılımlarıyla açıklanmıştır.

\section{Tema 1: Komşuluk İlişsilerine Yönelik Görüşler}

$\mathrm{Bu}$ tema başlığı altında, çalışma grubundaki bireylerin mültecilerle iletişim farklılıkları ve komşuluk ilişkilerindeki farklılıklarının nedenleri ele alınmıştır. Çalışma grubuna, Suriyeli mültecilerle iletişim farklılığ yaşayıp yaşamadıkları sorulmuş ve \%56,4 oranında $(n=232)$ iletişim farklılığı olduğu cevabı alınmıştır. Suriyeli mültecilerle komşuluk ilişkilerinde farklılık olup olmadığ 1 sorusuna ise $\% 42,2$ 'si $(\mathrm{n}=199)$ komşuluk ilişkilerinin farklı olduğu cevabını vermişlerdir. Katılımcıların Suriyeli mültecilerle ilişkilerinde yaşadıkları iletişim ve komşuluk ilişkilerinin farklılıklarının nedenlerine ilişkin görüşleri Tablo 1'de verilmiştir.

Tablo 1. Suriyeli Mültecilerle İletişim ve Komşuluk İlişsilerinin Farklılıklarının Nedenleri*

\begin{tabular}{|c|c|c|c|}
\hline $\begin{array}{c}\text { İletişim Farklılığının } \\
\text { Nedenleri }\end{array}$ & $\mathbf{N}$ & $\%$ & Örnek İfadeler \\
\hline Bireysel Farklılıklar & 145 & 62,5 & $\begin{array}{l}\text { Farklı kültürlere sahibiz ve burası onların ülkesi olmadığı için } \\
\text { kendilerini buraya ait hissetmediklerini düşünüyorum. Bu da } \\
\text { beraberinde bazı suç eylemlerini getiriyor, tedirgin oluyorum. } \\
\text { Tanıdığım mülteciler de diğerlerinden uzak durmamı söylüyor } \\
(201 \mathrm{~K} 38) \text {. }\end{array}$ \\
\hline Olumlu Bakış Açısı & 37 & 15,9 & $\begin{array}{l}\text { İletişimimin farklı yönü biraz daha ilgili ve hassasiyetli } \\
\text { davranıyor olmam (231K19). }\end{array}$ \\
\hline Duygusal Nedenler & 26 & 11,2 & $\begin{array}{l}\text { En azından bazılarına daha hassas yaklaşmaya çalışıyorum. } \\
\text { Savaş kötü, o yüzden üzülüyorum }(349 \mathrm{~K} 53) \text {. }\end{array}$ \\
\hline Olumsuz Bakış Açısı & 24 & 10,3 & $\begin{array}{l}\text { Suriyeli mülteciler mazlum, kalabalık ve cahil oldukları için } \\
\text { fırsatını bulduklarında topluma her türlü zararı verebilecek } \\
\text { yığınlar olarak görüyorum (195E45). }\end{array}$ \\
\hline \multicolumn{4}{|l|}{$\begin{array}{l}\text { Komşuluk İlişkileri } \\
\text { Farklılığı Nedenleri }\end{array}$} \\
\hline Bireysel Farklılıklar & 119 & 59,8 & $\begin{array}{l}\text { Örf-adetleri farklı, belli kuralları var. Yaşam tarzları bize uygun } \\
\text { değil (77E37). }\end{array}$ \\
\hline Olumsuz Bakış Açısı & 54 & 27,1 & $\begin{array}{l}\text { Komşuluk ilişkisi genelde yakıı gördüğün kişsilerle olur, bunları } \\
\text { yakın ve sıcak bulmuyorum (369K37). }\end{array}$ \\
\hline Duygusal Nedenler & 17 & 8,5 & $\begin{array}{l}\text { Onların mülteci olduklarını düşünerek biraz daha hassas } \\
\text { davranmaya gayret ediyorum }(131 \mathrm{~K} 46) \text {. }\end{array}$ \\
\hline Olumlu Bakış Açısı & 9 & 4,5 & $\begin{array}{l}\text { Diğer komşularımdan daha yakın görüyorum, çünkü diğer } \\
\text { komşularımız hiç iyi değil. Onlar daha iyi ve samimiler } \\
\text { (294E19). }\end{array}$ \\
\hline
\end{tabular}

*Birden fazla sayıda cevap verilmiştir. 
Tablo 1'de, katılımcıların \%62,5'inin Suriyeli mültecilerle bireysel farkl1lıklar nedeniyle iletişimlerinin farklı olduğunu ifade ettiği görülmektedir. Bunu olumlu bakış açısı $(\% 15,9)$, duygusal nedenler $(\% 11,2)$ ve olumsuz bakış açısı $(\% 10,3)$ izlemektedir. Konuyla ilgili olarak katılımcılardan bazıları görüşlerini şu şekilde dile getirmiş̧lerdir:

- (201K38) "Farklı kültürlere sahibiz ve burası onların ülkesi olmadığı için kendilerini buraya ait hissetmediklerini düşünüyorum. Bu da beraberinde bazı suç eylemlerini getiriyor, tedirgin oluyorum. Tanıdığım mülteciler de diğerlerinden uzak durmamı söylüyor."

- (231K19) "İletişimimin farklı yönü biraz daha ilgili ve hassasiyetli davranıyor olmam."

- (349K53) "En azından bazılarına daha hassas yaklaşmaya çalışıyorum. Savaş kötü, o yüzden üzülüyorum."

- (195E45) "Suriyeli mülteciler mazlum, kalabalık ve cahil oldukları için firsatını bulduklarında topluma her türlü zararı verebilecek yı̆̆ınlar olarak görüyorum."

Katılımcıların \%59,8'inin Suriyeli mültecilerle bireysel farklılıklar nedeniyle komşuluk ilişkilerinin farklı olduğunu ifade ettiği görülmektedir. Bunu olumsuz bakış açısı $(\% 27,1)$, duygusal nedenler $(\% 8,5)$ ve olumlu bakış açısı $(\% 4,5)$ izlemektedir. Konuyla ilgili olarak katılımcılardan bazıları görüşlerini şu şekilde dile getirmişlerdir:

- (77E37) "Örf adetleri farklı, belli kuralları var. Yaşam tarzları bize uygun değil.."

- (369K37) "Komşuluk ilişkisi genelde yakın gördüğün kişilerle olur, bunları yakın ve sıcak bulmuyorum."

- (131K46) "Onların mülteci olduklarını düşünerek biraz daha hassas davranmaya gayret ediyorum."

- (294E19) "Diğer komşularımdan daha yakın görüyorum, çünkü diğer komşularımız hiç iyi değil. Onlar daha iyi ve samimiler."

Katılımcıların, çoğunlukla Suriyeli mültecilerle ilgili endişeleri olduğu, olumlu yaklaşımlarının onların durumunu anlayarak hassas yaklaşmaya çalışmalarından kaynaklandığı söylenebilir. Genel olarak ifadelerinde "mülteci" kavramını kullandıkları da dikkat çeken noktalar arasındadır. Katılımcıların genel olarak Suriyeli mültecilerin farklılıkları ve onları samimi bulmamaları nedeniyle komşuluk ilişkileri kurmadıkları, komşuluk ilişkisi kuranların ise mültecilerin durumlarını anlayışla karşılamalarından kaynaklandığı söylenebilir.

\section{Tema 2: Mültecilerin Uyum Güçlüklerine Yönelik Görüşler}

$\mathrm{Bu}$ tema başlığı altında, mültecilerin yaşadıkları uyum güçlüklerinin nedenleri ve arkadaşlık ilişkilerindeki farkl1l1kların nedenleri üzerinde durulmuştur. Mültecilerin ülkenin kültürüne uyum sağlamakta güçlük çekip çekmediğine ilişkin soruya, katılımcıların $\% 63,1$ ’i güçlük çektiklerini, arkadaşl1k kurmak isteyip istemediklerine ilişkin soruya \%38,7'si arkadaşlık kurmak istemediklerini belirtmişlerdir. Katılımcıların Suriyeli mültecilerin uyum gücüklerinin nedenleri ve arkadaşlık ilişkilerinin farklılıklarının nedenlerine ilişkin görüşleri Tablo 2'de verilmiştir.

Tablo 2. Suriyeli Mültecilerin Uyum Güçlükleri ve Arkadaşlık İlişkilerinin Farklılıklarının Nedenleri*

\begin{tabular}{|c|c|c|c|}
\hline $\begin{array}{l}\text { Uyum Güçlüğünün } \\
\text { Nedenleri }\end{array}$ & $\mathrm{N}$ & $\%$ & Örnek İfadeler \\
\hline Kültür ve Dil Farklılığ1 & 264 & 94,6 & $\begin{array}{l}\text { Çünkü her insan kendi yaşadığı toplumun gelenekleriyle } \\
\text { görenekleriyle, ahlaki değerleriyle ve diliyle yetişir. Tamamen } \\
\text { zit bir ortama girdikleri için tam adapte olamıorlar (135K20). }\end{array}$ \\
\hline Ekonomik Nedenler & 6 & 2,1 & \\
\hline Olumsuz Bakış Açısı & 5 & 1,8 & $\begin{array}{l}\text { Kültürel değerlerimize yeterince saygı duyduklarını ve } \\
\text { öğrenmeye çalıştıklarını, uyum sağlamak istediklerini } \\
\text { düşünmüyorum (94K35). }\end{array}$ \\
\hline Duygusal Nedenler & 4 & 1,4 & $\begin{array}{l}\text { Kendi mülteci komşum da uyum çekmekte zorlandiğını } \\
\text { söylüyor, memleketlerini özlediklerini söylüyorlar. Uyum } \\
\text { zorluğu çekmelerinin nedeni bu bence ( } 50 \mathrm{~K} 49) \text {. }\end{array}$ \\
\hline $\begin{array}{l}\text { Arkadaşlık İlişkileri } \\
\text { Farklılığı Nedenleri }\end{array}$ & & & \\
\hline
\end{tabular}




\begin{tabular}{|c|c|c|c|}
\hline İstememe / Sevmeme & 38 & 28,6 & $\begin{array}{l}\text { Çünkü Türkiye'de kalmalarını doğru bulmuyorum ve } \\
\text { sevmiyorum }(316 \mathrm{~K} 18) .\end{array}$ \\
\hline İletişimde Zorluk & 22 & 16,5 & $\begin{array}{l}\text { İletişim kurmuyoruz, çünkü zor oluyor anlaşamadığımız için } \\
\text { (124E18). }\end{array}$ \\
\hline Kültür ve Görüş Farkı & 19 & 14,3 & $\begin{array}{l}\text { Ne konuştuklarını anlamadığım, giyimleri ve hareketleri } \\
\text { değişik olduğu için (147E18). }\end{array}$ \\
\hline $\begin{array}{l}\text { Olumsuz Davranış ve } \\
\text { Tutumlar }\end{array}$ & 18 & 13,5 & $\begin{array}{l}\text { Çok farklı insanlar. Genel olarak insanları art niyetli } \\
\text { görüyorum, samimi görmüyorum. Toplumumuza zarar } \\
\text { veriyorlar }(155 \mathrm{E} 56) \text {. }\end{array}$ \\
\hline Güvenememe & 16 & 12,0 & $\begin{array}{l}\text { Onlara korku ile yaklaştığımdan dolayı arkadaşlık kurmak } \\
\text { istemem }(128 \mathrm{~K} 40)\end{array}$ \\
\hline Önyargilar & 15 & 11,3 & $\begin{array}{l}\text { Biz onları dışlamazken ülkemizin yani evimizin kapısını } \\
\text { açmışken onlar bizi dişlayıp beğenmiyorlar. Türkleri } \\
\text { sevmediklerini söylüyorlar. Anlaşabileceğimi düşünmüyorum } \\
(94 \mathrm{~K} 25) \text {. }\end{array}$ \\
\hline Ayrımcılık & 5 & 3,7 & $\begin{array}{l}\text { İletişim kurmak istemem, çünkü her öncelik onlara sunuluyor } \\
\text { (308K39). }\end{array}$ \\
\hline
\end{tabular}

*Birden fazla sayıda cevap verilmiştir.

Tablo 2'de, katılımcıların \%94,6'sının Suriyeli mültecilerle kültür ve dil farklılıkları nedeniyle uyum sorunu olduğunu ifade ettiği görülmektedir. Bunu ekonomik nedenler $(\% 2,1)$, olumsuz bakış açısı $(\% 1,8)$ ve duygusal nedenler $(\% 1,4)$ izlemektedir. Konuyla ilgili olarak katılımcılardan bazıları görüşlerini şu şekilde dile getirmişlerdir:

- (135K20) "Çünkü her insan kendi yaşadığı toplumun gelenekleriyle görenekleriyle, ahlaki değerleriyle ve diliyle yetişir. Tamamen zit bir ortama girdikleri için tam adapte olamıorlar."

- (182E35) "İstihdama katkı sağlamaları gerekmektedir."

- (94K35) "Kültürel değerlerimize yeterince saygı duyduklarını ve öğrenmeye çalıştıklarını, uyum sağlamak istediklerini düşünmüyorum."

- (50K49) "Kendi mülteci komşum da uyum çekmekte zorlandığını söylüyor, memleketlerini özlediklerini söylüyorlar. Uyum zorluğu çekmelerinin nedeni bu bence."

Katılımcıların \%28,6'sının Suriyeli mültecilerle arkadaşlık ilişkileri kurmamalarının nedeni onları istemedikleri/sevmedikleri içindir. Bunu sırasıyla iletişimde zorluk $(\% 16,5)$, kültür ve görüş fark1 $(\% 14,3)$, olumsuz davranış ve tutumlar $(\% 13,5)$, güvenememe $(\% 12)$, önyargılar $(\% 11,3)$, ayrımcılık $(\% 3,7)$ izlemektedir. Konuyla ilgili olarak katılımcılardan bazıları görüşlerini şu şekilde dile getirmişlerdir:

- (147E18) "Ne konuştuklarını anlamadığım için, giyimleri ve hareketleri değişik olduğu için."

- (155E56) "Çok farklı insanlar genel olarak insanları art niyetli görüyorum samimi görmüyorum toplumumuza zarar veriyorlar."

- $\quad$ (94K25) "Biz onları dışlamazken ülkemizin yani evimizin kapısını açmışken onlar bizi dışlayıp beğenmiyorlar, Türkleri sevmediklerini söylüyorlar. Anlaşabileceğimi düşünmüyorum.”

Katılımcıların genel olarak Suriyeli mültecilerin kültürel ve dil farklılıkları nedeniyle uyum güçlüğü yaşadıkları görüşünde oldukları söylenebilir. Arkadaşlık kurmama nedenleri ise yine kültürel ve dil farklılıkları nedeniyle iletişim kuramamaları ve mültecilerin olumsuz davranışlarını görüp onları sevmemeleri, önyargilar olarak sayılabilir.

\section{Tema 3: Mültecilerin Toplum Yapısına Etkilerine İlişsin Görüşler}

$\mathrm{Bu}$ tema başlığı altında, katılımcıların mültecilerin toplum yapısına olumsuz etkileri ve istenmeyen davranışları ele alınmıştır. Mültecilerin gelmesiyle toplumun olumsuz yönde etkilenip etkilenmediğine ilişkin olarak katılımcıların \%75,6's1 olumsuz etkilendiğini, \%64,7'si mültecilerin istenmeyen/olumsuz davranışları bulunduğunu belirtmişlerdir. Bu olumsuzlukların neler olduğuna ilişkin görüşleri Tablo 3’te verilmişsir. 
Tablo 3. Mültecilerin Toplumdaki Olumsuz Etkileri*

\begin{tabular}{|c|c|c|c|}
\hline $\begin{array}{l}\text { Topluma Olumsuz } \\
\text { Etkileri }\end{array}$ & $\mathbf{N}$ & $\%$ & Örnek İfadeler \\
\hline Ekonomik olumsuzluklar & 106 & 30,6 & $\begin{array}{l}\text { Aşırı mülteci gelmesiyle birden onlara da aynı imkânı sağlamak için } \\
\text { daha çok para harcandı. Bu da ekonomik olarak olumsuz yönde } \\
\text { etkiledi. İşsizlik oranı arttı (224K30). }\end{array}$ \\
\hline $\begin{array}{l}\text { Sosyal alandaki } \\
\text { uyumsuzluklar }\end{array}$ & 87 & 25,1 & $\begin{array}{l}\text { Herkesin ayırt edilmeden dışardan alınması. Bir terör örgütüne } \\
\text { bağlı olabilir, ülkeye onları alarak olanak veriliyor. Aynı şekilde } \\
\text { onların da bizi farklı görmesi, insanların birbirlerine daha fazla kin, } \\
\text { nefret duymasına sebep ( } 27 \mathrm{~K} 21) \text {. }\end{array}$ \\
\hline Suç oranındaki artış & 36 & 10,4 & $\begin{array}{l}\text { Hırsızlık çoğaldı, tacizler yaşandı. Türkiye'de öyle insanlar var ama } \\
\text { onlar daha kötü çıktılar. Ekonomik açıdan da zorluk yaşıyoruz } \\
\text { dileniyorlar. Evleri de çok pis kullanıyorlar. Yıkık evlerin yanına } \\
\text { tuvalet yaptıklarına bile şahit olduk. Bazıları gerçekten pis insanlar } \\
(50 \mathrm{~K} 49) \text {. }\end{array}$ \\
\hline Ayrımcılık & 24 & 6,9 & $\begin{array}{l}\text { Onlara çeşitli ayrıcalıklar verildiği ve vatandaşlık verilmesi } \\
\text { hususunda sorunlar yaşanıyor. Ülkemize çok fazla ve Avrupa } \\
\text { ülkeleri gibi seçici bir alım yapılmadı. Eğitimli, yaşlı ve kadın } \\
\text { olarak seçilmesi daha doğru olurdu (6K21). }\end{array}$ \\
\hline Güvensizlik & 23 & 6,6 & $\begin{array}{l}\text { Gelmelerini kötü bulmuyorum kesinlikle. Etkilenmeden ziyade bir } \\
\text { etki oluştu diyebilirim. Kendinden görememe, ne zaman } \\
\text { gidiyorlarsa gitsinler bakışı (eğitimlerini vs düşünmek yerine } \\
\text { gitmelerini düşünmek) ve bazı mültecilerin hatalı davranışları da bu } \\
\text { görüşlerin oluşmasına neden oldu (16K20). }\end{array}$ \\
\hline Kisitlanma & 22 & 6,4 & $\begin{array}{l}\text { Sosyal alanlarda fazla rahatlar, ülkemizde yasak olan şeyleri } \\
\text { yapıyorlar, bizi k1sitliyorlar }(3 \mathrm{~K} 21) \text {. }\end{array}$ \\
\hline Hızlı nüfus artışı & 15 & 4,3 & $\begin{array}{l}\text { Bizlerden fazla onları görmek ülkemde kaygı oluşturmama neden } \\
\text { oluyor neden en çok Türk toplumunun içindeler ( } 46 \mathrm{~K} 22) \text {. }\end{array}$ \\
\hline Ahlakın bozulması & 14 & 4,0 & $\begin{array}{l}\text { Toplumumuz onların gösterdiği hal ve hareketlerden etkileniyor, } \\
\text { ahlaki olarak sıkıntı oluyor (117K29). }\end{array}$ \\
\hline Sağlık sorunları & 8 & 2,3 & $\begin{array}{l}\text { Yani onlar çok kötü şartlardan kaçarak ülkemize gelmişler ve } \\
\text { beraberinde farklı hastalıklar da gelmiş oldu, bu da toplumu } \\
\text { olumsuz etkiler }(227 \mathrm{~K} 21) \text {. }\end{array}$ \\
\hline Fırsatçılık yapılması & 6 & 1,7 & $\begin{array}{l}\text { Onların gelmesiyle bizim insanımız fırsatçılık yapıp fiyatları her } \\
\text { şeyde yükseltti (17K18). }\end{array}$ \\
\hline Eğitim sorunları & 5 & 1,4 & $\begin{array}{l}\text { Karma bir topluluk oldukça toplumsal kargaşa da arttı. Çünkü } \\
\text { sosyal ve kültürel seviyesi düşük olan insanların da ülkemizde } \\
\text { yaşamaya başlamasıyla sosyal yaşamda problemler çıtı, bu durum } \\
\text { halka yansıdı (7E23). }\end{array}$ \\
\hline \multicolumn{4}{|l|}{$\begin{array}{l}\text { İstenmeyen } \\
\text { Davranışları }\end{array}$} \\
\hline Toplumsal düzeni bozma & 53 & 19,8 & $\begin{array}{l}\text { Sokak ortasında uygunsuz davranma, yüksek sesle konuşmak gibi } \\
\text { (67E34). }\end{array}$ \\
\hline $\begin{array}{l}\text { Dilencilik/duygu } \\
\text { sömürüsü }\end{array}$ & 49 & 18,4 & $\begin{array}{l}\text { Yollarda çocuklarıyla sürekli dilenerek ya da kendilerine yardımcı } \\
\text { olanlara zarar verici davranışta bulunarak hoş olmayan şeyler } \\
\text { yapıyorlar }(6 \mathrm{~K} 21) \text {. }\end{array}$ \\
\hline $\begin{array}{l}\text { Hirsızlık ve } \\
\text { dolandirıcılık }\end{array}$ & 40 & 15,0 & $\begin{array}{l}\text { Saygısızlar, başkalarının haklarını gasp ediyorlar, kadınları rahatsız } \\
\text { ediyorlar, erkeklerimize farklı amaçlarla yaklaşıyorlar (50K49). }\end{array}$ \\
\hline $\begin{array}{l}\text { Cinsel suçlar, terör ve } \\
\text { cinayet }\end{array}$ & 39 & 14,6 & $\begin{array}{l}\text { Sokakta, parkta ve caddede insanlarımızı taciz ediyorlar. Suç } \\
\text { oranları arttı }(301 \mathrm{~K} 50) \text {. }\end{array}$ \\
\hline
\end{tabular}




\begin{tabular}{|c|c|c|c|}
\hline Kabalık & 34 & 12,7 & Argo kelimeler kullanıyorlar ve saygısızlar (233K18). \\
\hline Kavga/şiddet & 24 & 9,9 & $\begin{array}{l}\text { Kendi ülkelerinde yaşayamadıkları rahatlığı burada yaşamaktalar } \\
\text { ama yine de memnun kalmayıp toplu halde gezip kavga } \\
\text { çıartıyorlar (356K33). }\end{array}$ \\
\hline Ahlaki yapıyı bozma & 9 & 9,0 & $\begin{array}{l}\text { K1z erkek fark etmeksizin hakaret içerikli konuşmalar, çok fazla } \\
\text { dilenme ve değerlerimize önem vermeme ( } 46 \mathrm{~K} 22) \text {. }\end{array}$ \\
\hline Çevreye zarar verme & 8 & 3,3 & $\begin{array}{l}\text { Motorlarına abartı egzoz takıyorlar, çevreyi de kirletiyorlar sürekli } \\
\text { (239E18). }\end{array}$ \\
\hline Doyumsuzluk/açgözlülük & 5 & 3,0 & $\begin{array}{l}\text { Hepsini aynı kefeye koyamayız ama içlerinde azımsanmayacak } \\
\text { ölçüde olumsuz davranış sergileyenler var. Onlara her konuda } \\
\text { cömert davranan insanlarımızın masum duygularını istismar } \\
\text { edenler ve memnuniyetsiz olanlar gibi diyebiliriz (143K39). }\end{array}$ \\
\hline Çok eşlilik & 4 & 1,5 & $\begin{array}{l}\text { Sosyal hayatta aile yapısına zarar verdiler. Kadın mültecilerin } \\
\text { ülkemizde ikinci eş olarak alınmaları ve kuma olmaları gibi }(9 \mathrm{~K} 36) \text {. }\end{array}$ \\
\hline Ucuz maliyetli işçilik & 2 & 0,7 & $\begin{array}{l}\text { Ülkenin her şeyinden faydalandıkları için vergi vermemekteler, } \\
\text { ucuza çalıştıkları için de toplumumuzda işsizlik arttı (369K37). }\end{array}$ \\
\hline
\end{tabular}

*Birden fazla sayıda cevap verilmiştir.

Tablo 3'e göre katılımcıların \%30,6'sı Suriyeli mültecilerin toplumdaki olumsuz etkilerini ekonomik olumsuzluklar olarak ifade etmişlerdir. Bunu sırasıyla sosyal alandaki uyumsuzluklar $(\% 25,1)$, suç oranındaki artış $(\% 10,4)$, ayrımcılık $(\% 6,9)$, güvensizlik $(\% 6,6)$, kısıtlanma $(\% 6,4)$, hızlı nüfus artışı $(\% 4,3)$, ahlakın bozulması $(\% 4)$, sağlık sorunları $(\% 2,3)$, firsatçılık yapılması $(\% 1,7)$ ve eğitim sorunları $(\% 1,4)$ izlemektedir. Konuyla ilgili olarak katılımcılardan bazıları görüşlerini şu şekilde dile getirmişlerdir:

- (27K21) "Herkesin ayırt edilmeden dışardan alınması. Bir terör örgütüne bağlı olabilir ülkeye onları alarak olanak veriliyor. Aynı şekilde onların da bizi farklı görmesi, insanların birbirlerine daha fazla kin, nefret duymasina sebep."

- (50K49) "Hırsızlık çoğaldı, tacizler yaşandı. Türkiye'de öyle insanlar var ama onlar daha kötü çıktılar. Ekonomik açıdan da zorluk yaşıyoruz dileniyorlar. Evleri de çok pis kullanıyorlar. Yıkık evlerin yanına tuvalet yaptıklarına bile şahit olduk. Bazıları gerçekten pis insanlar."

- (117K29) “Toplumumuz onların gösterdiği hal ve hareketlerden etkileniyor, ahlaki olarak sikintı oluyor."

Katılımcıların \%19,8'i Suriyeli mültecilerin toplumdaki düzeni bozucu davranışları istemediklerini belirtmişlerdir. Bunu sırasıyla dilencilik/duygu sömürüsü $(\% 18,4)$, hırsızlık ve dolandırıcılık (\%15), cinsel suçlar, terör ve cinayet $(\% 14,6)$, kabalık $(\% 12,7)$, kavga/şiddet $(\% 9,9)$, ahlaki yapıyı bozma $(\% 9)$, çevreye zarar verme $(\% 3,3)$, doyumsuzluk/açgözlülük $(\% 3)$, çok eşlilik $(\% 1,5)$ ve ucuz maliyetli işçilik $(\% 0,07)$ izlemektedir. Konuyla ilgili olarak katılımcılardan bazıları görüşlerini şu şekilde dile getirmişlerdir:

- (6K21) "Yollarda çocuklarıyla sürekli dilenerek ya da kendilerine yardımcı olanlara zarar verici davranışta bulunarak hoş olmayan şeyler yapıyorlar."

- (369K37) "Ülkenin her şeyinden faydalandıkları için vergi vermemekteler, ucuza çalıştıkları için de toplumumuzda işsizlik arttı."

- (143K39) "Hepsini aynı kefeye koyamayız ama içlerinde azımsanmayacak ölçüde olumsuz davranış sergileyenler var. Onlara her konuda cömert davranan insanlarımızın masum duyguların istismar edenler ve memnuniyetsiz olanlar gibi diyebiliriz."

Katılımcıların genel olarak, Suriyeli mültecilerin toplumda ekonomik ve sosyal alanda olumsuzluklara neden olduğu görüşünde oldukları; katılımcılar tarafından toplumsal düzeni bozan, hırsızlık, dilencilik, kavga ve suç teşkil edebilecek davranışlarının istenmediği söylenebilir. 


\section{Tema 4: Mültecilerin Yaşam Koşullarının İyileştirilmesine İlişskin Görüşler}

$\mathrm{Bu}$ tema başlı̆g 1 altında, katılımcıların mültecilerin toplum yapısına olumsuz etkileri ve istenmeyen davranışları ele alınmıştır. Mültecilerin yaşam koşullarında iyileştirme yapılması gereken konulara ilişkin olarak katılımcıların \%52,1'i iyileşme yapılması gerektiğini, \%76,7'si ise ülkelerine dönmeleri gerektiğini belirtmişlerdir. İyileştirme gereken konular ve mültecilerin ülkelerine dönmeleri gerektiğgine ilişkin görüşler Tablo 4'te verilmiştir.

Tablo 4. Mültecilerin Yaşam Koşullarında İyileştirilmesi Gereken Konular ve Ülkelerine Dönmelerini Gerektiren Nedenler*

\begin{tabular}{|c|c|c|c|}
\hline $\begin{array}{l}\text { İyileştirme Gereken } \\
\text { Konular }\end{array}$ & $\mathbf{N}$ & $\%$ & Örnek İfadeler \\
\hline $\begin{array}{l}\text { Barınma, gıda, giyim } \\
\text { gibi temel ihtiyaçlar }\end{array}$ & 89 & 43,2 & $\begin{array}{l}\text { Yaşam olarak yaşadıkları evler, çadır kentlerin durumu biraz daha } \\
\text { iyileştirilmeli. Gıda ve giyecek yardımı yapılmalı. En azından temel } \\
\text { ihtiyaçları koşulsuz şartsız sağlanmalıdır (228K22). }\end{array}$ \\
\hline Eğitim & 38 & 18,4 & $\begin{array}{l}\text { Eğitimleri eksik bırakılmamalı ülkeye gelen her mülteci takip } \\
\text { edilmeli. Sadece mültecilerin değil her insanın yaşam koşulları } \\
\text { iyileştirilmeli. Bu da tüm bu insanlarda bilinç dönüşümü olursa olur } \\
(33 \mathrm{~K} 21) \text {. }\end{array}$ \\
\hline İş & 34 & 16,5 & $\begin{array}{l}\text { Ekonomik anlamda, yerleşim ve iş istihdamı konusunda } \\
\text { iyileştirilmeliler. Belki o zaman hırsızlık ve dilencilikleri azalır } \\
(50 \mathrm{~K} 49) \text {. }\end{array}$ \\
\hline Topluma uyum & 23 & 11,2 & $\begin{array}{l}\text { Eğitim, barınma, sağlık, beslenme, giyinme yani tüm temel ihtiyaçlar } \\
\text { sağlanmalı yetenekli işçiler istihdam edilmeli. Ama hepsine eğitimle } \\
\text { Türk dili öğretilmeli ki toplumdaki anlaşmazlıklar ortadan kalksın } \\
\text { (6K21). }\end{array}$ \\
\hline Sağlık & 13 & 6,3 & $\begin{array}{l}\text { İlk olarak yaşadıkları ortama bağlı gelişen sağlık sıkıntıları } \\
\text { iyileştirilmeli (120E65). }\end{array}$ \\
\hline Dil & 9 & 3,4 & $\begin{array}{l}\text { Yaşadıkları ülkeye daha kolay adapte olabilmeleri için dil eğitimi vb. } \\
\text { konularda destek olunmalı. Özellikle mesleklerini yapıp kendi } \\
\text { geçimlerini temin etmelerine firsat verilmeli (18K23). }\end{array}$ \\
\hline \multicolumn{4}{|l|}{$\begin{array}{l}\text { Ülkelerine Dönmelerini } \\
\text { Gerektiren Nedenler }\end{array}$} \\
\hline Kişisel hak ve özgürlük & 110 & 38,5 & $\begin{array}{l}\text { Çünkü kendi toprakları kendi evleri ve kendi yaşam bölgeleri varken } \\
\text { kimse başka bir yerde misafir olarak yaşamak istemez. Herkesin } \\
\text { benimsediği bir yurt ve kültür vardır. Birbirlerine uyum sağlamaya } \\
\text { çalışmak yerine hâlihazırda bildikleri bir yerde yaşamaları onlar için } \\
\text { de daha huzurlu ve güvenli olacaktır (7E23). }\end{array}$ \\
\hline $\begin{array}{l}\text { Bizim ülkemizin yararı } \\
\text { için }\end{array}$ & 105 & 36,7 & $\begin{array}{l}\text { Çünkü Türkiye'de geçim sıkıntısı var. Ülkemizin kaldıracağı yük } \\
\text { değiller. Onlar için de Türkiye için de zor. Bir an önce ülkelerine } \\
\text { gitsinler ki geçimimiz ferahlasın. Ülkenin her yerinde çoğaldılar } \\
\text { memleketimdeki çoban bile Suriyeliymiş (50K49). }\end{array}$ \\
\hline $\begin{array}{l}\text { Kendi ülkeleri yararı } \\
\text { için }\end{array}$ & 71 & 28,8 & $\begin{array}{l}\text { Çünkü onların ülkesi orası ve ülkelerine sahip çıkmalılar. Diğer } \\
\text { ülkelerin desteği ile ülkelerini yeniden düzenlemeliler. Yaşlılar, } \\
\text { kadınlar, çocuklar ya da eğitim dışında burada yaşayanlar bizim } \\
\text { vicdanen rahatsız olmamıza neden oluyor. Savaşabilecek durumdaki } \\
\text { erkeklerin TSK'dan eğitim alıp kendi ülkeleri için savaşmaları } \\
\text { gerekiyor. Ülkemizin kuruluşunda verdiğimiz savaşı onlar da kendi } \\
\text { ülkeleri adına omuz omuza vermelidirler (6K21). }\end{array}$ \\
\hline
\end{tabular}

*Birden fazla sayıda cevap verilmiştir.

Tablo 4'e göre katılımcıların \%43,2'si Suriyeli mültecilerin barınma, gıda, giyim gibi temel ihtiyaçlarının karşılanması konusunda iyileştirme yapılması gerektiği görüşündedirler. Bunu sırasıyla eğitim $(\% 18,4)$, iş $(\% 16,5)$, topluma uyum $(\% 11,2)$, sağl1k $(\% 6,3)$ ve dil $(\% 3,4)$ izlemektedir. Konuyla ilgili olarak katılımcılardan bazıları görüşlerini şu şekilde dile getirmişlerdir:

- (33K21 "Eğitimleri eksik birakılmamalı ülkeye gelen her mülteci takip edilmeli. Sadece mültecilerin değil her insanın yaşam koşulları iyileştirilmeli. Bu da tüm bu insanlarda bilinç dönüşümü olursa olur.” 
- (6K21) "Eğitim, barınma, sağlık, beslenme, giyinme yani tüm temel ihtiyaçlar sağlanmalı yetenekli işçiler istihdam edilmeli. Ama hepsine eğitimle Türk dili öğretilmeli ki toplumdaki anlaşmazlıklar ortadan kalksın. En azından temel ihtiyaçları koşulsuz şartsız sağlanmalıdır."

- (50K49) "Ekonomik anlamda, yerleşim ve iş istihdamı konusunda iyileştirilmeliler. Belki o zaman hırsızlık ve dilencilikleri azalır."

- (18K23) "Yaşadıkları ülkeye daha kolay adapte olabilmeleri için dil eğitimi vb. konularda destek olunmalı. Özellikle mesleklerini yapıp kendi geçimlerini temin etmelerine firsat verilmeli."

Katılımcıların \%38,5'i Suriyeli mültecilerin kişisel hak ve özgürlükleri için, \%36,7'si Türkiye'nin yararı için ve \%28,8'i kendi ülkelerinin yararı için ülkelerine dönmeleri gerektiğini belirtmişlerdir. Konuyla ilgili olarak katılımcılardan bazıları görüşlerini şu şekilde dile getirmişlerdir:

- (7E23) "Çünkü kendi toprakları kendi evleri ve kendi yaşam bölgeleri varken kimse başka bir yerde misafir olarak yaşamak istemez. Herkesin benimsediği bir yurt ve kültür vardır. Birbirlerine uyum sağlamaya çalışmak yerine hâlihazırda bildikleri bir yerde yaşamaları onlar için de daha huzurlu ve güvenli olacaktır."

Katılımcıların genel olarak, Suriyeli mültecilerin temel gereksinimlerinin karşılanmasında iyileştirmelere ihtiyaç olduğu görüşünde oldukları hem temel hak ve özgürlükleri hem de her iki ülkenin yararına olacağı için ülkelerine dönmeleri gerektiği görüşünde oldukları söylenebilir.

\section{Tema 4: Katılımcıların Mültecilere İlgili Görüş̧lerindeki Değişim}

$\mathrm{Bu}$ tema başlığı altında, katılımcıların mültecilerle ilgili görüşlerindeki değişimler ele alınmıştır. Suriyeli mültecilerle ilgili olarak katılımcıların \%26,7'si görüşlerinin değiştiğini belirtmişlerdir. Değişen görüşlere ilişkin konuların dağılımı Tablo 5 'te verilmiş̧tir.

Tablo 5. Suriyeli mülteciler hakkında değişen görüşler*

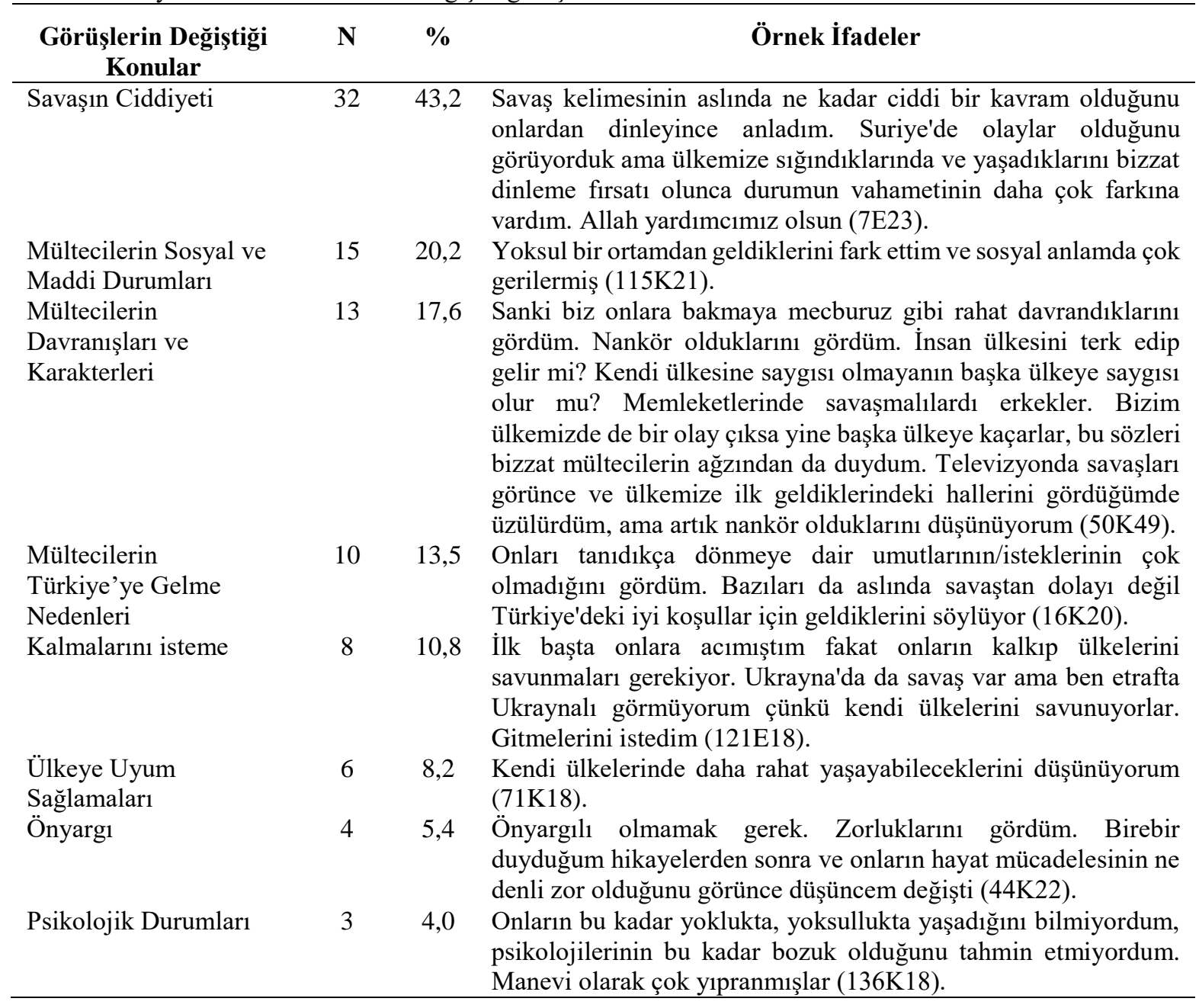


*Birden fazla sayıda cevap verilmiştir.

Tablo 5'e göre katılımcıların \%43,2'si Suriyeli mülteciler sayesinde savaşın ciddiyetini daha iyi anladıklarını belirtmişlerdir. Görüşlerin değişmesine ilişkin olarak sırasıyla mültecilerin sosyal ve maddi durumları $(\% 20,2)$, mültecilerin davranışları ve karakterleri $(\% 17,6)$, mültecilerin Türkiye’ye gelme nedenleri $(\% 13,5)$, ülkeye uyum sağlamaları $(\% 8,2)$, önyargılar $(\% 5,4)$ ve mültecilerin psikolojik durumları (\%4) konularında görüşlerinde değişiklikler olduğunu belirtmişlerdir. Konuyla ilgili olarak katılımcılardan bazıları görüşlerini şu şekilde dile getirmişlerdir:

- (7E23) "Savaş kelimesinin aslında ne kadar ciddi bir kavram olduğunu onlardan dinleyince anladım. Suriye'de olaylar olduğunu görüyorduk ama ülkemize sığındıklarında ve yaşadıklarını bizzat dinleme firsatı olunca durumun vahametinin daha çok farkına vardım. Allah yardımcımız olsun."

- (121E18) "İlk başta onlara acımıştım fakat onların kalkıp ülkelerini savunmaları gerekiyor. Ukrayna'da da savaş var ama ben etrafta Ukraynalı görmüyorum, çünkü kendi ülkelerini savunuyorlar. Gitmelerini istedim.” Şeklinde düşüncelerini dile getirmişlerdir.

- (136K18) "Onların bu kadar yoklukta, yoksullukta yaşadığını bilmiyordum, psikolojilerinin bu kadar bozuk olduğunu tahmin etmiyordum. Manevi olarak çok yıpranmışlar."

Katılımcıların genel olarak, Suriyeli mültecilerin Türkiye'ye gelmelerinden sonra savaşın ciddiyeti ve mültecilerin yaşadıklarına yönelik görüşlerinde değişiklikler olduğu görülmektedir. Özellikle, savaşmak yerine ülkelerini bırakıp gelmelerine pek hoş bakmadıkları söylenebilir.

\section{Tartışma}

$\mathrm{Bu}$ araştırmada farklı yaş grubundan bireylerin Türkiye'deki Suriyeli mültecilere ilişkin bazı görüşleri incelenmiştir. Çalışmada, katılımcıların, çoğunlukla Suriyeli mültecilerle ilgili endişelerinin olduğu, olumlu yaklaşımlarının onların durumunu anlayarak hassas yaklaşmaya çalışmalarından kaynaklandığı belirlenmiştir. Suriyeli mültecilerin farklılıkları ve onları samimi bulunmamaları nedeniyle komşuluk ilişkileri kurmadıkları, komşuluk ilişkisi kuranların ise mültecilerin durumlarını anlayışla karşılamalarından kaynaklandığı belirlenmiştir. Çalışmada, katılımcıların Suriyeli mültecilerin kültürel ve dil farklılıkları nedeniyle uyum güçlüğü yaşadıkları görüşünde oldukları belirlenmiştir. Onlarla arkadaşlık kurmama nedenleri; kültürel ve dil farklılıkları nedeniyle iletişim kuramama, mültecilerin olumsuz davranışlarını görüp onları sevmeme ve önyargılar olarak belirlenmiştir.

Alan yazında, yerel halkın yabancı bireylere karşı farklı bakış açısıyla yaklaştıklarını ortaya koyan çalışmalar mevcuttur. Dedeoğlu ve Ekiz Gökmen (2011), Türk halkının Müslüman olmayan bireylere yabancı gözüyle baktıklarını belirlemişlerdir. Bu durum, mültecilerin kendi dini veya farklı bir dinden olan toplumla bir arada yaşamalarının da sorunları etkileyeceğini göstermektedir. Yapılan bu çalışmada, din birliğinin olması sorunları biraz daha azaltmış olabilir. Bunun dışında kültürel ve dil farkları, yaşanan uyum güçlügünde önemli bir yer almış olabilir.

Kat1lımcıların genel olarak, Suriyeli mültecilerin toplumda ekonomik ve sosyal alanda olumsuzluklara neden olduğu görüşünde oldukları; Suriyelilerin toplumsal düzeni bozan, hırsızlık, dilencilik, kavga ve suç teşkil edebilecek davranışlarının istenmediği belirlenmiştir. Çalışmaya katılan bireylerin genel olarak, Suriyeli mültecilerin temel gereksinimlerinin karşılanmasında iyileştirmelere ihtiyaç olduğu görüşünde oldukları; hem temel hak ve özgürlükleri hem de her iki ülkenin yararına olacağ için ülkelerine dönmeleri gerektiği görüşünde oldukları belirlenmiştir. Son olarak katılımcıların, Suriyeli mültecilerin Türkiye'ye gelmelerinden sonra savaşın ciddiyeti ve mültecilerin yaşadıklarına yönelik görüşlerinde değişiklikler olduğu, özellikle savaşmak yerine ülkelerini bırakıp gelmelerine pek hoş bakmadıkları belirlenmiştir.

Adıbatmaz (2017), 8-14 yaş arası sığınmacı çocukların sorunlarını incelediği çalışmada, sığınmacı çocukların akran zorbalığı ile karşılaştıklarını, kendilerini ötekileştirilmiş hissettiklerini belirlemiştir. Sığınmacı çocuklarla görüşülerek yapılan çalışmadaki bu bulgu, yerel halkla görüşme yöntemiyle 
yapılan bu çalışma bulgularıyla benzer niteliktedir. Hem sığınmacı hem de yerel halkın bu durumdan çeşitli rahatsızlıkları olduğu söylenebilir.

Son günlerde yaşananlar, iç savaş ve terör tüm dünyada ciddi bir mülteci sorununa neden olmuştur. Suriye iç savaşı ise, en büyük göçmen krizini ortaya çıkarmıştır. Savaş sonucu oluşan göçlerde, bireyler göç ettikleri yerlerde de çeşitli ciddi sorunlar yaşamaktadırlar. Döner (2016), Suriye'de yaşanan iç çatışmalardan dolayı Hatay ilindeki mültecilerin yerel halkla yaşadığı sorunları araştırdığı çalışmasında hem mülteciler hem de yerel halkla görüşmeler yapmıştır. Sonuç olarak, yaşanan sorunların başında, Suriyeli mültecilerin düşük ücretle çalışması ve hayat pahalılığının artması geldiğini belirlemiştir. Ayrıca, iki halk arasındaki kültürel fark ve medyanın kışkırtıcı dil kullanması, tarafların birbirleriyle karşı karşıya gelmelerine neden olmuştur. Duruel (2017) Suriye sınırında yer alan Hatay ilindeki sığınmacıların karşılaştıkları sorunları incelediği çalışmasında, en öncelikli sorunlarının istihdam, güvenlik, sağlık ve eğitim problemleri olduğunu belirlemiştir. Bunun dışında gida temini, sosyal uyum, dil ve iletişim problemi, hukuki statüleri, siyasal hakları gibi konularda sorunlar yaşadıkları belirlenmiştir. Buna göre, yerel halkın rahatsız olduğu durumlar yanında Suriyeli mültecilerin de yaşadıkları durumdan hoşnut olmadığı pek çok durum olduğu söylenebilir. $\mathrm{Bu}$ sonuçlar, çalışma bulgularını destekler niteliktedir.

Pandır, Efe ve Paksoy (2015), Türk basınında Suriyeli sığınmacı temsillerini inceledikleri çalışmalarında gazetelerdeki Suriyeli sığınmacılarla ilgili haber ve görsellerin içeriklerinin çoğunlukla olumlu ya da yansız özelliklere sahip olduğu, temsillerde bir ikilem olduğunu belirlemişlerdir. Temsiller Suriyeli sığınmacıyı zorlu koşullar içinde "yoksul” ve "yardıma muhtaç" olarak gösterirken, aynı sıklıkta toplum güvenliği için bir "tehdit" olarak da göstermektedir. Kabaklı Çimen ve Eroy Quadır (2018), üniversite öğrencileriyle yaptıkları çalışmada yaşı büyük olan öğrencilerin Suriyeli sığınmacılara karşı daha 1lımlı bir bakış açısına sahip olduklarını, onlara yardım ettiklerini ve haklarını savunduklarını belirlemişlerdir. Bunun yanında, öğrencilerin dini inanç düzeyleri arttıkça daha olumsuz fikirlere sahip oldukları, radikal kararlara ve düşük düzeyde 1lımlı kararlara katıldıkları belirlenmiş̧ir. Bu bulguların çalışma bulgularını desteklediği söylenebilir.

Genel olarak göç, toplumları ve devletleri olumsuz yönde etkilemektedir. Bu etki jeopolitik, ekonomik ve kültürel pek çok değişime de neden olabilmektedir (Deniz, 2014). Türkiye'ye kitlesel olarak giriş yapan Suriyeliler, Türkiye'de günlük yaşamın bir parçası haline gelmiştir. Oluşturulan kamplar dışında yaşayan çok sayıda Suriyeli bulunmaktadır. Bu durum, ülkede yaşanan pek çok sorunu daha da artırmaktadır (Mackreath ve Sağnıç, 2017). Göç, doğal olarak hem göç eden hem de göç edilen toplum açısından farklı etkiler oluşturmaktadır (Mann, 2006). Yaşamın bir gereği olan göçün, tüm dünyada iki yönlü olarak ele alınması ve sorunların çözümünün hem toplum hem de devletler bazında ele alınması gereken bir konu olduğu söylenebilir.

\section{Sonuç ve Öneriler}

Suriyeli mülteciler ve yerli halk arasında toplumsal uyum ve dil konusunda bazı problemler yaşanmaktadır. Halk, mültecilerle aynı dili konuşamadığı için iletişim kurmakta zorlanmaktadır. Yerli halk Suriyeli mültecilere maddi ve manevi destek vermekle beraber yaşanan problemlerin acilen çözülmesini ya da en kısa sürede kendi ülkelerine dönmelerini istemektedir.

Suriyeli mülteciler hakkındaki başlıca sorunlar arasında işsizlik, istihdam, kültür çatışması ve dil sorunları yer almaktadır. Problemlerin çözümü için ilk tercih mültecilerin kendi ülkelerine dönmeleridir. İkinci tercih ise Suriyelilere yönelik özelleştirilmiş eğitim programlarının düzenlenmesi ve ülkemiz vatandaşlarına bilinçlendirme çalışmalarının yapılmasıdır.

Günümüzde mülteci bireylerin sosyal durumları, kültürel ve dil gibi farklılıklarından dolayı topluma uyum zorlukları çektikleri bilinmektedir. Mülteci bireylerin sorunları gibi Türkiye'de yaşamakta olan bireylerin sorunları da hiç kuşkusuz küresel insan hakları sorunudur ve göç ile ilgili en önemli nokta, "toplumsal kabul", "kültürel uyum" sorunlarının çözülebilmesidir. Son yıllarda birçok ülke, göç nedeni ne olursa olsun, toplumsal yaşam içinde göçmen tabanlı sorunlarla mücadele etmek, toplumsal 
kabul ve kültürel uyum konularını çözmek için göçmenlere yönelik eğitimler, sosyal konular ve ekonomi alanında çeşitli politikalar geliştirmektedir.

Araştırma sonuçlarına genel olarak bakıldığında mülteciler ve yerli halk birbirini tanımadığı için sorunlar yaşanmaktadır. O yüzden tanışıp kaynaşmayı, bireylerin birbirlerini anlamalarını sağlayacak etkinlikler düzenlenebilir. Hem mültecilere hem ülkedeki insanlara durum hakkında ayrıntılı bilgi verecek çalışmalar yapılabilir. İşsizlik ve istihdam problemi için devlet destekli personel çalıştırma teşviki yapılabilir.

Mültecilerin ülkemiz vatandaşları hakkındaki görüşleri incelenebilir. Bu araştırma ile karşıllaştırılarak çözüm yolları önerilebilir.

\section{Kaynakça}

Ağır, O., \& Sezik, M. (2015). Suriye'den Türkiye'ye yaşanan göç dalgasından kaynaklanan güvenlik sorunlar1. Birey ve Toplum Dergisi, 5(9), 96-97.

Baş, M., Molu, B., Tuna, H. İ., \& Baş, İ. (2017). Göç eden ailelerin sosyo-kültürel ve ekonomik değişiminin kadın ve çocuk yaşamına etkisi. Insan ve Toplum Araştırmaları Dergisi, 6(3), 1680-1693.

Beter Ö. (2006). Sinırlar ötesi umutlar: mülteci çocuklar. Ankara: Sabev.

Castles, S., \& Miller M.J. (2008). Göçler çağı: Modern Dünyada Uluslararası Göç Hareketleri, (B.U. Bal ve İ. Akbulut, Çev.). İstanbul: Bilgi Üniversitesi.

Chambers, I. (2005). Göç, kültür, kimlik. (İ. Türkmen ve M: Beşikçi, Çev.). İstanbul: Ayrıntı. Çepni, S. (2005). Araştırma ve proje çalışmalarına giriş. Trabzon: Üçyol Kültür Merkezi.

Dedeoğlu, S., \& Ekiz Gökmen, Ç. (2011). Göç ve sosyal dışlanma. Ankara: Elif.

Deniz, T. (2014). Uluslararası göç sorunu perspektifinden Türkiye. Türkiye Sosyal Araştırmalar Dergisi, 181, 175-204.

Deniz, O., \& Etlan, E. (2009). Kırdan kente göç ve göçmenlerin uyum süreci üzerine bir çalışma: Van örneği. Uluslararası İnsan Bilimleri Dergisi, 6(2), 472-498.

Döner, H. (2016). Suriyeli göçmenlerle yaşanan sorunlar üzerine sosyolojik bir araştırma: Hatay ili örneği (Yayımlanmamış Yüksek Lisans Tezi). Fırat Üniversitesi Sosyal Bilimler Enstitüsü. Elazı̆g.

Duruel, M. (2017). Suriyeli sığınmacıların karşılaştıkları temel sorunlar ve beklentiler: Hatay örneği. Akademik Bakış Uluslararası Hakemli Sosyal Bilimler E-Dergisi, 62, 57-79.

Ekiz, D. (2003). Eğitimde araştırma yöntem ve metodlarına giriş. Ankara: Anı.

Erdoğan, M. (2017). Türkiye'de yaşayan Suriyeli mültecilere yönelik medya algısı. Liberal Perspektif Analiz Dergisi, 5, 9-10.

Giddens, A., \& Sutton, P.W. (2014). Sosyolojide Temel Kavramlar. (A. Esgin, Çev.). Ankara: Phoenix.

Gök, G. O. (2016). Kimin güvenliği? Uluslararası göç-güvenlik ilişkisi ve uluslararası örgütlerin rolü. KOSBED, 31, 65-82.

Gözübüyük, A. A., Duras, E., Dağ, H., \& Arıca, V. (2015). Olağan üstü durumlarda çocuk sağlığı. Journal of Clinical and Experimental Investigations, 3, 324-330.

Güçtürk, Y. (2014). Sürgün ile savaş arasında suriyeli mülteciler. Siyaset, Ekonomi ve Toplum Araştırmaları Vakfı (SETA), Ankara. http://setav.org/tr/5-soru-surgun-ilesavasarasinda-suriyeli-multeciler/yorum/18059 adresinden 15.05.2015 tarihinde alınmıştır.

Güven, S. (1996). Uluslararası işçi göçünün sosyal politika sorunları. Bursa: Uludağ Üniversitesi.

https://bianet.org/bianet/toplum/167434-multeci-gocmen-siginmaci-arasindaki-farklar. (2019). Mülteci, göçmen, sığınmacı arasındaki farklar. 04.02.2019 tarihinde alınmıştır. 
Kabaklı Çimen, L., \& Ersoy Quadır, S. (2018). Üniversite öğrencilerinin Suriyeli sığınmacılarla ilgili tutumlarının sivil katılımları bağlamında incelenmesi. Insan ve Toplum Bilimleri Araştırmaları Dergisi, 7(2), 1251-1273.

Kağnıc1, D. Y (2017). Suriyeli mülteci çocukların kültürel uyum sürecinde okul psikolojik danışmanlarına düşen rol ve sorumluluklar. İlköğretim Online, 16(4), 1768-1776.

Kane, H. (1995). Leaving home. society, 12(4). [Electronic Journal] http://search.global.epnet.com1 adresinden 24.12.2014 tarihinde alınmıştır.

Karasar, N. (2007). Bilimsel araştırma yöntemi. Ankara: Bilim Kitap Kırtasiye.

Keser, A., \& Meral, E. (2016). Türk hava sahasını ihlal eden rus uçağının düşürülmesi: uluslararası anlaşmalar ve hukuk çerçevesinde bir inceleme. Türk Sosyal Bilimler Araştırmaları Dergisi, 1(1), 29-44.

Kızılçelik, S., \& Erjem, Y. (1994). Açıklamalı sosyoloji terimler sözlüğü. Ankara: Atilla.

Kirişçi, K. (1996). Coerced immigrants: Refugees of Turkish origins since 1945. International Migration, 34(3), 385-412.

Küçükkaraca, N. (2001). Göç ve çalışan çocuklar: Diyarbakır'da çalışan çocuklar. Sosyal Hizmet Sempozyumu. 20-22 Ekim Diyarbakır, Ocak-Şubat-Mart 2001.

Li, P.S. (2008). World migration in the age of globalization: Policy implications and challenges. New Zealand Population Review, 33(34), 1-22.

Mackreath, H., \&Sağnıç, Ş. G. (2017). Civil society and Syrian refugees in Turkey (Ed. A.Çavdar, \& F. Genç). İstanbul: Zer Matbaa.

Mann, M. A. (2006). The formation and development of individual and ethnic identity: Insights from psychiatry and psychoanalytic theory. The American Journal Psychoanalyisis, 66(2), 211-224.

Ortadoğu Stratejik Araştırmalar Merkezi. (ORSAM). (2015). Suriye'ye komşu ülkelerde suriyeli mültecilerin durumu: bulgular, sonuçlar ve öneriler, Rapor No: 189, Ankara.

Ortadoğu Stratejik Araştırmalar Merkezi (ORSAM) \& Türkiye Ekonomik ve Sosyal Etüdler Vakfı (TESEV). (2015). Suriyeli sığınmacıların Türkiye'ye etkileri, Rapor No: 195, Ankara.

Özmen, N. (2012). Çok kültürlü toplumda sosyal entegrasyon ve din. İstanbul: Çamlıca.

Pandır, M., Efe, İ., \& Paksoy, A. (2015). Türk basınında Suriyeli sığınmacı temsili üzerine bir içerik analizi. Marmara Illetişim Dergisi, 24, 1-26.

Poyraz-Tacoğlu, T., Arıkan, G. \& Sağır, A. (2012). Boşnak göçmenlerde göç ve kültürel kimlik ilişkisi: Fevziye köyü örneği. Turkish Studies, 7(1), 941-965.

Şener, D.K., \& Ocakçı, A.F. (2014). Yoksulluğun çocuk sağlığı üzerine çok boyutlu etkileri. Ankara Sağllk Hizmetleri Dergisi, 13(1), 57-68.

Tatlılığlu, D. (2012). Göç sosyolojisi açısından hicret. İstanbul: Asitan.

Yalçın, C. (2004). Göç Sosyolojisi. Ankara: Anı.

Yavuz, Ö. (2015). Türkiye'deki Suriyeli mültecilere yapılan sağlık yardımlarının yasal ve etik temelleri. Mustafa Kemal Üniversitesi Sosyal Bilimler Enstitüsü Dergisi, 12(30), 265280.

Yıldırım, A., \& Şimşek, H. (2005). Sosyal bilimlerde nitel araştırma yöntemleri. Ankara: Seçkin. 